\title{
Detection and molecular characterization of rabies virus in Mongolia during 2008-2010
}

\author{
Bumduuren Tuvshintulga ${ }^{1}$, Enkhbaatar Batmagnai ${ }^{1}$, Enkhbold Bazarragchaa ${ }^{2}$, Purevtseren Dulam ${ }^{2}$, Sengee Sugar ${ }^{2}$ and \\ Badgar Battsetseg ${ }^{1}$
}
1. Laboratory of Molecular Genetics, Institute of Veterinary Medicine, Mongolian, University of Life Science, Zaisan, 17024 Ulaanbaatar, Mongolia; 2. State Central Veterinary Laboratory, Zaisan, 17024 Ulaanbaatar, Mongolia. Corresponding author: Badgar Battsetseg, e-mail: Bata07@gmail.com, BT: tuvshintulga@gmail.com, EBat: magnai1987@gmail.com, EB: bazarragchaa@scvl.gov.mn,PD: dulampurevtseren@yahoo.com, SS: ssugar352000@yahoo.com
Received: 29-07-2015, Revised: 31-08-2015, Accepted: 08-09-2015, Published online: 27-09-2015

How to cite this article: Tuvshintulga $B$, Batmagnai $E$, Bazarragchaa $E$, Dulam $P$, Sugar S, Battsetseg B. Detection and molecular characterization of rabies virus in Mongolia during 2008-2010. Int J One Health 2015;1:26-31.

\begin{abstract}
Aim: We aimed to investigate the prevalence and molecular characterization of rabies virus (RABV) from wild and domestic animals in Mongolia during 2008-2010.

Materials and Methods: Brain tissue samples were collected from 24 rabid animals in Zavkhan, Omnogovi, Tov, Dundgovi, Govi-Altai, Selenge, Ovorkhangai, and Khentii provinces in Mongolia. Herein, samples were included from 13 domestic animals (dogs, cattle, camels, sheep, and goat) and 11 wild animals (wolves and foxes) in this study. Direct fluorescent antibody (DFA) test and reverse transcriptase polymerase chain reaction (RT-PCR) were performed for detection of RABV, and positive samples were further processed for molecular characterization of the virus using nucleoprotein gene. Subsequently, the molecular characterization was determined based on the nucleoprotein gene.
\end{abstract}

Results: Out of 24 samples, 22 samples were detected positive for RABV by DFA test, and its nucleoprotein gene was amplified in all of the 24 samples by RT-PCR. These Mongolian RABVs were classified within steppe-type virus clade by phylogenetic analysis of nucleoprotein gene sequences. This steppe-type virus clade was clearly divided by two Sub-clades (A and B). The most of Mongolian RABVs belongs to the Sub-clade A in the phylogenetic tree.

Conclusion: These findings have clearly confirmed RABV in domestic and wild animals of Mongolia. Further molecular characterization indicated that this Mongolian strain is steppe-type virus clade consisting of two sub-clades; the Subclade A might be prevalent in Altai, Khangai, Khentii Mountains as a major genotype, whereas the Subclade B seems to be cosmopolitan in the steppe-type virus clade, is spread in northern central Eurasia.

Keywords: detection, molecular characterization, Mongolia, rabies virus, sub-clade A, subclade B.

\section{Introduction}

Rabies is a re-emerging zoonotic viral disease caused by rabies virus (RABV), which belongs to the genus Lyssavirus, family Rabdoviridae. RABV is a nonsegmented and negative sense $12 \mathrm{~kb}$ RNA virus. The genomic RNA consists of five encoding protein genes, including nucleoprotein $(\mathrm{N})$, phosphoprotein $(\mathrm{P})$, matrix protein $(\mathrm{M})$, glycoprotein $(\mathrm{G})$, and polymerase (L) genes [1]. $\mathrm{N}$ gene is commonly used for molecular detection and phylogenetic analysis as it is highly conserved among Lyssavirus [2].

RABV infects warm blood animals including human, upon bite by rabid carnivorous animals. Human deaths mainly occur in Asia and Africa, especially case occurs in the rural areas [3]. Mongolia is a landlocked country, geographically located in the Eastern central Asia, besides Kazakhstan to the west side, and sandwiched with Russia to the north side, and China to the south side. In Mongolia, the occurrence of rabies has been recorded since 1950,

Copyright: The authors. This article is an open access article licensed under the terms of the Creative Commons Attributin License (http:// creative commons.org/licenses/by/2.0) which permits unrestricted use, distribution and reproduction in any medium, provided the work is properly cited. and the first report was associated with a rabid fox in the early 1960s [4]. In 1965, 2175 domestic and 232 wild animal rabies deaths occurred in Sukhbaatar province, and at that time several rabies cases were reported in the neighboring 6 provinces in Mongolia during 1965-1968. Further, during 1970-2005, RABV was responsible for deaths in 21302 animals and 34 human [5]. Botvinkin et al. first determined molecular characterization of RABV isolated from 4 rabid animals from Western parts of Mongolia, which are classified within steppe-type virus clade [4]. Furthermore, Boldbaatar et al. also determined RABVs within steppe-type virus clades, except one Mongolian RABV that is classified together with arctic-like virus clade in animal rabies cases from Bayan-Olgii, GoviAltai, Zavkhan, Khovsgol, and Tov provinces during 2005-2008 [6].

In the last few years, Mongolian rabies cases are not available to the public. In Russia and Kazakhstan, rabies is frequently occurring in animals and human, caused by five groups including arctic-like (phylogeny clade B) and steppe-type (phylogeny clade C) virus clades [7]. In China, rabies is commonly reported in the Southern provinces such as Guangxi, Guangdong, Hunan, and Guizhou [8,9]. As for the Northern 
provinces in China, rabies is recently reported in Xinjiang and inner Mongolia in China, caused by steppe-type virus and arctic-like rabies clades $[10,11]$. In the present study, we investigated molecular characterization of Mongolian RABV among wild and domestic animals during 2008-2010 collected from different geographical regions (Ovorkhangai, Dundgovi, Omnogovi, Khentii, and Selenge provinces) $[4,6]$.

\section{Materials and Methods \\ Ethical approval}

The present study was conducted at Laboratory of Molecular Genetics, Institute of Veterinary Medicine, in Mongolia, while brain samples were obtained from dead animals, according to safety precautions in handling procedure.

\section{Samples}

Brain tissue samples were collected from 24 animals including wild animals $(\mathrm{n}=11,3$ wolves, 8 foxes) and domestic animals ( $\mathrm{n}=13,4$ dogs, 4 cattle, 2 camels, 2 sheep, and 1 goat) during 2008-2010 and samples were stored at $-30^{\circ} \mathrm{C}$ until further use. These animals belong to 8 provinces of Mongolia (GoviAltai, Dundgovi, Zavkhan, Ovorkhangai, Omongovi, Khentii, Selenge and Tov) (Table-1 and Figure-1).

\section{Direct fluorescent antibody test (DFA)}

DFA was performed by the manufacturer's instruction using Light diagnostics ${ }^{\mathrm{TM}}$ rabies DFA reagent (Millipore Ltd., Livingston, UK, cat. no. 5100). Briefly, brain impressions from the cerebellum and hippocampus were prepared on slides and were fixed by dipping in cold acetone at $-20^{\circ} \mathrm{C}$ for $30 \mathrm{~min}$. Slides were taken out and dried in air.
Fluorescein isothiocyanate-labelled anti-rabies monoclonal antibody was added on the marked spot and slides were incubated in a humid chamber at $37^{\circ} \mathrm{C}$ for $30 \mathrm{~min}$. These slides were rinsed by $\times 1$ phosphate buffered saline at 3 times for $5 \mathrm{~min}$. Mounting fluid was dropped on the spot on the slides and examined under fluorescent microscopy.

RNA extraction and reverse transcriptase-polymerase chain reaction (RT-PCR) assay

Total RNA was extracted using TRIzol $^{\circledR}$ (Invitrogen, Life Technology, Paisly, UK, cat. no. 15596-018), according to manufacturer's instruction. Briefly, $50 \mathrm{mg}$ brain tissue was homogenized by micro-grinder with disposable pestle. Total RNA was purified by Trizol and chloroform. After isopropyl alcohol precipitation, the RNA was dissolved in $30 \mu 1$ of double distilled and RNA-free water, and stored at $-80^{\circ} \mathrm{C}$ until use.

RT-PCR was performed in GeneAmp ${ }^{\circledR}$ thermocycler 9700 following previously described method [12]. Briefly, cDNA was synthesized using TaqMan ${ }^{\circledR}$ RT reagent Kit (Applied Biosystems, California, USA, cat. no. N8080234). Briefly, $1 \mu 1$ total RNA was added in RT-reaction mixture containing $\times 1$ RT buffer, $1.75 \mathrm{mM} \mathrm{MgCl}, 0.5 \mathrm{mM}$ each deoxynucleotide triphosphates (dNTPs), $5 \mathrm{mM}$ dithiothreitol, $1 \mathrm{U}$ RNase inhibitor, $0.5 \mu \mathrm{M}$ JW12 (ATGTAACACC $(\mathrm{C} / \mathrm{T}$ ) CTACAATTG) sense primer, $2.5 \mathrm{U}$ MultiScribe RT, and RNA-free DDW. RT-reaction conditions were as follows: Denaturation of RNA at $96^{\circ} \mathrm{C}$ for $2 \mathrm{~min}, \mathrm{RT}$ at $42^{\circ} \mathrm{C}$ for $45 \mathrm{~min}$, deactivation of RT at $95^{\circ} \mathrm{C}$ for $5 \mathrm{~min}$, store at $4^{\circ} \mathrm{C}$. cDNA was amplified by JW12 sense and JW6 mixture anti-sense primers (JW6DPL: CAATTCGCACACATTTTGTG;

Table-1: Sampling locations, source, and detection of RABV in this study.

\begin{tabular}{|c|c|c|c|c|c|}
\hline GenBank accession number & Hosts & County (Region/province) & Year & DFA & RT-PCR \\
\hline KT338628 & Cattle & Selenge & 2008 & - & + \\
\hline KT338631 & Cattle & Ovorkhangai & 2008 & - & + \\
\hline KT338630 & Dog & Dundgovi & 2009 & + & + \\
\hline KT338632 & Cattle & Dundgovi & 2009 & + & + \\
\hline KT338615 & Camel & Omnogovi, Mandal-Ovoo & 2010 & + & + \\
\hline KT338616 & Cattle & Tov, Bayankhangai & 2010 & + & + \\
\hline KT338617 & Dog & Dundgovi, Erdenedalai & 2010 & + & + \\
\hline KT338619 & Sheep & Dundgovi, Khuld & 2010 & + & + \\
\hline KT338623 & Camel & Omnogovi, Mandal-Ovoo & 2010 & + & + \\
\hline KT338624 & Dog & Zavkhan, Tsagaankhairkhan & 2010 & + & + \\
\hline KT338626 & Sheep & Tov, Shireet & 2010 & + & + \\
\hline KT338627 & Goat & Govi-Altai, Khaliun & 2010 & + & + \\
\hline KT338637 & Dog & Khentii & 2010 & + & + \\
\hline KT338629 & Fox & Dundgovi & 2008 & + & + \\
\hline KT338614 & Wolf & Zavkhan, Uliastai & 2009 & + & + \\
\hline KT338618 & Fox & Dundgovi, Erdenedalai & 2010 & + & + \\
\hline KT338620 & Fox & Dundgovi, Khuld & 2010 & + & + \\
\hline KT338621 & Fox & Dundgovi, Ulziit & 2010 & + & + \\
\hline KT338622 & Fox & Omnogovi, Manlai & 2010 & + & + \\
\hline KT338625 & Wolf & Zavkhan, Aldarkhaan & 2010 & + & + \\
\hline KT338633 & Fox & Dundgovi & 2010 & + & + \\
\hline KT338634 & Fox & Dundgovi & 2010 & + & + \\
\hline KT338635 & Wolf & Khentii & 2010 & + & + \\
\hline KT338636 & Fox & Khentii & 2010 & + & + \\
\hline
\end{tabular}

DFA=Direct fluorescent antibody, RT-PCR=Reverse transcriptase-polymerase chain reaction 


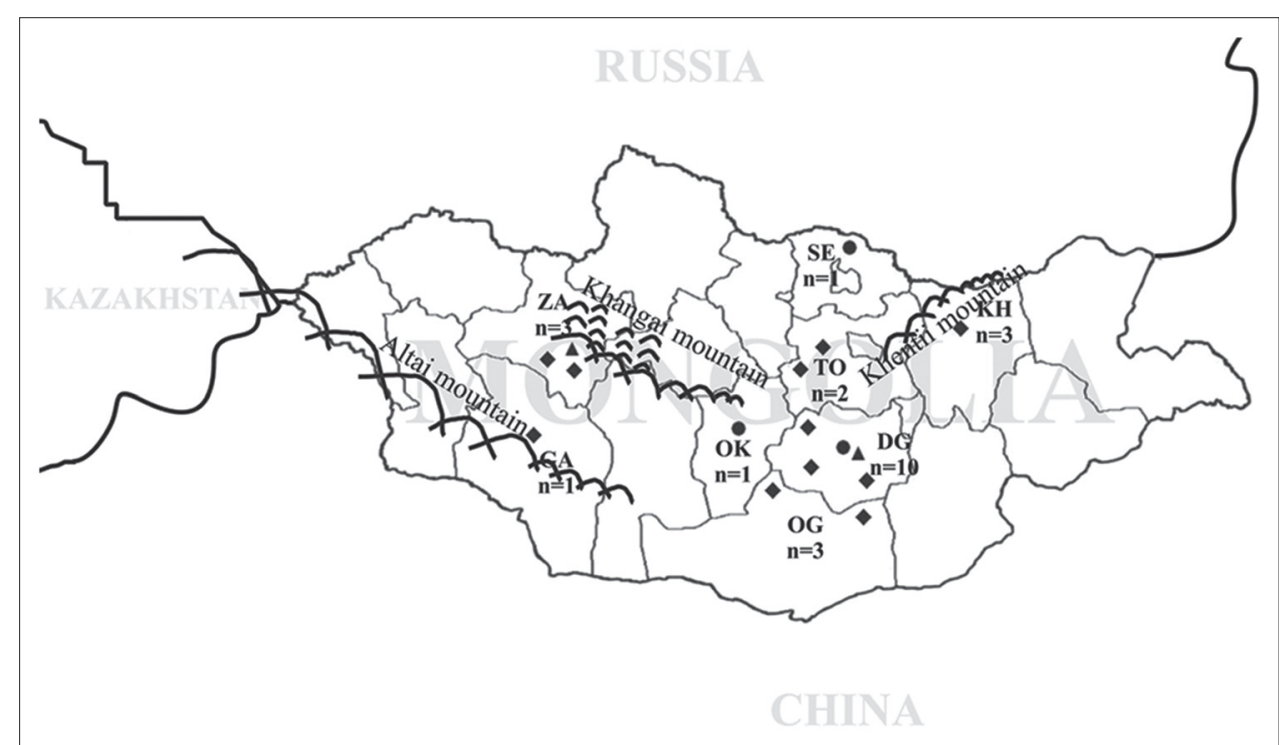

Figure-1: Sampling locations and sources of brain tissue samples in this study. Black circles, triangles, and diamonds indicate sampling year $2008(\boldsymbol{*}), 2009(\boldsymbol{\Delta})$, and $2010(\diamond)$, respectively. The name of provinces was abbreviated by GA (Govi-Altai), Dundgovi (DG), ZA (Zavkhan), OK (Ovorkhangai), OG (Omnogovi), KH (Khentii), SE (Selenge), and TO (Tov). Number of samples were indicated by abbreviation $(n=)$.

JW6E: CAGTTGGCACACATCTTGTG; JW6M; CAGTTAGCGCACATCTTATG) using AmpliTaq Gold $^{\circledR}$ PCR Master Mix (Applied Biosystems, California, USA, cat. no. 4327058), and $1 \mu 1 \mathrm{cDNA}$ was added in the PCR-mixture containing $\times 1$ PCR buffer, $1.5 \mathrm{mM} \mathrm{MgCl}, 0.2 \mathrm{mM}$ each dNTPs, $1 \mu \mathrm{M}$ each sense and anti-sense primers and $0.5 \mathrm{U}$ Taq polymerase, and distilled water. PCR-reaction conditions were: Denaturation at $95^{\circ} \mathrm{C}$ for $5 \mathrm{~min}$, amplification 40 cycles denaturation at $95^{\circ} \mathrm{C}$ for $30 \mathrm{~s}$, annealing at $45^{\circ} \mathrm{C}$ for $30 \mathrm{~s}$, elongation at $72^{\circ} \mathrm{C}$ for $30 \mathrm{~s}$, with a final elongation at $72^{\circ} \mathrm{C}$ for $10 \mathrm{~min}$. The PCR products were electrophoresed on 1.5\% agarose gel and stained with ethidium bromide. The amplified PCR products were visualized under ultraviolet light.

\section{Sequencing and phylogenetic analysis}

RT-PCR amplicons were directly sequenced on 3130xl Genetic Analyzer using BigDye ${ }^{\circledR}$ Terminator V 3.1 cycle sequencing kit (Applied Biosystems, California, USA, cat. no. 4337454) following instructions as per manual. Institute of Veterinary Medicine, Mongolia has sequencing facilities. The sequences were initially analyzed by basic local alignment search tool (http://blast.ncbi.nlm.nih.gov/Blast.cgi) and then analyzed by MatGAT 2.02 software [13] so as to calculate their identity scores. The phylogenetic tree was constructed by MEGA software version 6.06 [14] using a maximum likelihood method based on the Tamura 3-parameter model [15].

\section{Results and Discussion}

In the present study, the 2008-2010 reports of rabies in animals were updated to public knowledge. We collected brain tissue samples from 24 rabid wild and domestic animals. Out of 24 samples, RABV were detected from 22 samples by DFA (Table-1), whereas RT-PCR detected nucleoprotein gene fragment ( $606 \mathrm{bp}$ ) from all of the 24 samples. RT-PCR was found to be more sensitive than DFA in the detection of RABV positive samples. RT-PCR amplified minute quantity specific RNA isolated form the tissue samples, whereas DFA is qualitative and relative test [16]. The nucleotide sequence was initially analyzed to align from raw sequences of forward and reverse primers in each PCR amplicon, and then a total length of $442 \mathrm{bp}$ nucleotide sequence was determined from each PCR amplicon. This sequence is located between 71 and 512 positions in the genome of RABV. Identity scores of nucleotide sequences were shared $96.2 \%$ and $100 \%$ among Mongolian RABVs in the present study (Table-2). In the phylogenetic tree, Mongolian RABVs are classified within steppe-type virus clade in the Figure-2a. The steppe-type virus clade spreaded in a wide geographical region such as European parts, Kazakhstan, Russia, and Mongolia [5,7]. In contrast, this steppe-type virus clade was clearly divided by two sub-clades in the phylogenetic tree; Sub-clade A and B are supported with $76 \%$ and $25 \%$ of bootstrap values, respectively (Figure-2b). The most of Mongolian RABVs are classified within Sub-clade A, except a sequence from Buryatia in Russia, which is nearly bordered with the northern region of Mongolia. Probably, this Sub-clade A is only prevalent in regions of Altai, Khangai, Khentii Mountains, which are located in Mongolia (Figure-1). However, small parts of Altai Mountain are located along Kazakhstan, Russia, and China. As for the subclade B consisted of sequences of RABV viruses isolated from Mongolia, Russia, and Kazakhstan. It seems that subclade B has a wide range of prevalence in the northern part of Eurasia including Mongolia, Kazakhstan, Russia and some European regions [7]. A few number of Mongolian RABVs 


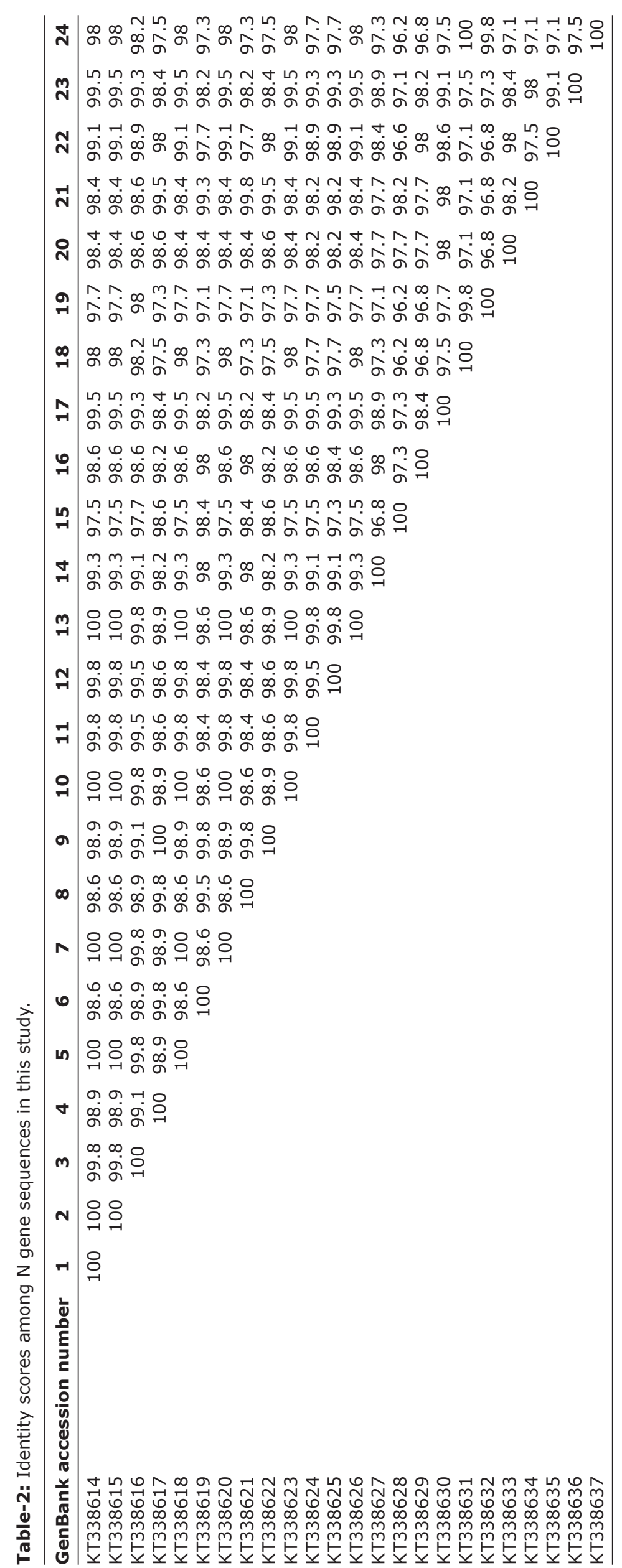




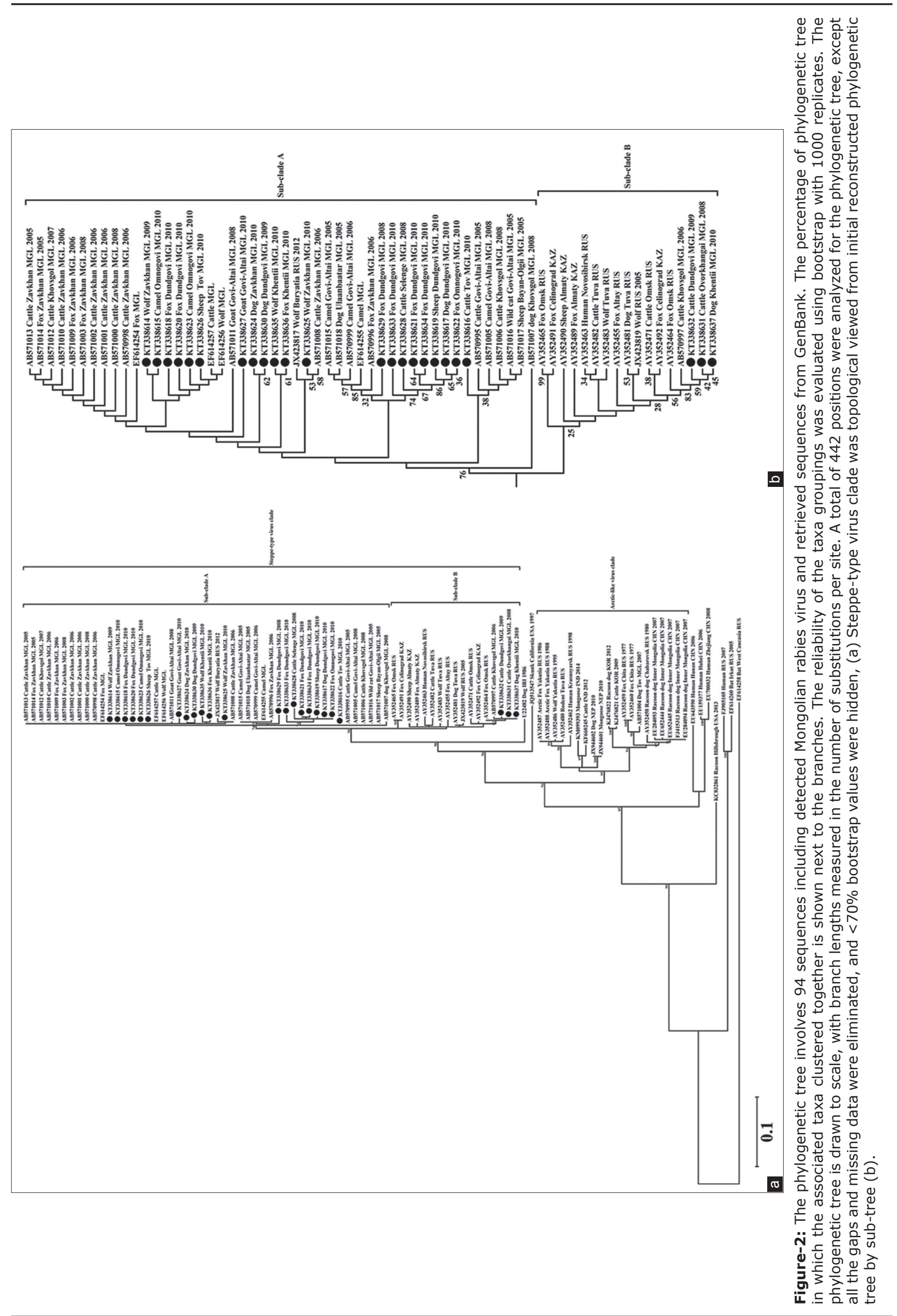


belong to Sub-clade B (Figure-2b). In the previous study (cases during 2005-2008), Mongolian RABVs were classified within steppe-type virus clade, except only an RABV, which belongs to arctic-like virus clade [6]. However, we cannot isolate arctic-like virus in the present study.

In summary, Mongolian RABVs mainly belongs to the Sub-clade A and B within steppe-type clade. The steppe-type viruses are widely distributed in Mongolia and mainly cause the incidence of rabies in wild and domestic animals. Particularly, the Sub-clade A might be a major dominant genotype of RABV in Mongolia.

\section{Authors' Contributions}

In the present study, BT has designed and performed all experiments under supervision of BB . EBat, EB, PD, and SS have contributed in sample preparation, experimental procedure and English language editing. All authors participated in draft and revision of the manuscript. All authors read and approved the final manuscript.

\section{Acknowledgments}

The authors are thankful to Mongolian Regional Veterinarians who helped to collect brain samples from countryside and special thanks to Dr. Sanjay Kumar (National Research Center on Equines, India) for English language editing. This research study was supported by Science and Technology Foundation, Ministry of Education and Science of Mongolia.

\section{Competing Interests} interests.

The authors declare that they have no competing

\section{References}

1. Yang J, Hooper DC, Wunner WH, Koprowski H, Dietzschold B, Fu ZF. The specificity of rabies virus RNA encapsidation by nucleoprotein. Virology 1998;242:107-17.

2. Kissi B, Tordo N, Bourhy H. Genetic polymorphism in the rabies virus nucleoprotein gene. Virology 1995;209:526-37.

3. World Health Organization. WHO Expert Consultation on Rabies. Second report. World Health Organ Tech Rep Ser 2013;1-139.

4. Botvinkin AD, Otgonbaatar D, Tsoodol S, Kuzmin IV. Rabies in the Mongolian steppes. Dev Biol (Basel) 2008;131:199-205.

5. Odontsetseg N, Uuganbayar D, Tserendorj SH, Adiyasuren Z. Animal and human rabies in Mongolia. Rev Sci Tech 2009;28:995-1003.

6. Boldbaatar B, Inoue S, Tuya N, Dulam P, Batchuluun D, Sugiura N, et al. Molecular epidemiology of rabies virus in Mongolia, 2005-2008. Jpn J Infect Dis 2010;63:358-63.

7. Kuzmin IV, Botvinkin AD, McElhinney LM, Smith JS, Orciari LA, Hughes GJ, et al. Molecular epidemiology of terrestrial rabies in the former Soviet Union. J Wildl Dis 2004;40:617-31.

8. Wang L, Tang Q, Liang G. Rabies and rabies virus in wildlife in mainland China, 1990-2013. Int J Infect Dis 2014;25:122-9.

9. Zhang HL, Zhang YZ, Yang WH, Tao XY, Li H, Ding JC, et al. Molecular epidemiology of reemergent rabies in Yunnan Province, southwestern China. Emerg Infect Dis 2014;20:1433-42.

10. Yin JF, Wang JL, Tang Q, Ding YL, Tao X, Li H, et al. Identification of animal rabies in Inner Mongolia and analysis of the etiologic characteristics. Biomed Environ Sci 2014;27:35-44.

11. Feng Y, Wang W, Guo J, Alatengheli, Li Y, Yang G, et al. Disease outbreaks caused by steppe-type rabies viruses in China. Epidemiol Infect 2015;143:1287-91.

12. Heaton PR, Johnstone P, McElhinney LM, Cowley R, O'Sullivan E, Whitby JE. Heminested PCR assay for detection of six genotypes of rabies and rabies-related viruses. J Clin Microbiol 1997;35:2762-6.

13. Campanella JJ, Bitincka L, Smalley J. MatGAT: An application that generates similarity/identity matrices using protein or DNA sequences. BMC Bioinformatics 2003;4:29.

14. Tamura K, Stecher G, Peterson D, Filipski A, Kumar S. MEGA6: Molecular Evolutionary Genetics Analysis version 6.0. Mol Biol Evol 2013;30:2725-9.

15. Tamura K. Estimation of the number of nucleotide substitutions when there are strong transition-transversion and G C-content biases. Mol Biol Evol 1992;9:678-87.

16. Biswal M, Ratho RK, Mishra B. Role of reverse transcriptase polymerase chain reaction for the diagnosis of human rabies. Indian J Med Res 2012;135:837-842. 